\title{
Opportunities and Threats for Innovative Import Substitution in Russia
}

\author{
Natalya Krivenko* \\ Institute of Economics of the Ural Branch of the Russian Academy of Sciences, 620014, \\ Moskovskaya St., 29, Ekaterinburg, Russian Federation
}

\begin{abstract}
The article examines the development of import substitution in Russia from the historical perspective, confirming the need for an innovative strategy instead of the model of catch-up development. The study investigates international and domestic approaches to the implementation and impact of innovations, noting achievements and considerable potential of Russian science. Analysis of certain economic indicators for the period 2017-2019 revealed positive trends in the development of agricultural industry, negative dynamics of industrial production, a decline in manufacturing production and growth in mining. A decrease in research and development expenditures and a decline in the number of design, design and survey organizations, and researchers led to a decrease in production share of high-tech and knowledge-intensive industries in gross domestic product. There is a slight increase in exports, including its share in world exports. The problems and achievements of import substitution are considered on the example of the agricultural and aviation industries. The SWOT analysis identified the strengths, weaknesses, opportunities, and threats for the development of Russian import substitution, considering the innovative component. Finally, the paper proposes an author's approach to a cross-sectoral assessment of import substitute products in order to create an effective import substitution mechanism, considering the innovative component.
\end{abstract}

Following the annexation of Crimea in mid-March 2014, the United States, the European Union, Australia, New Zealand and Canada have imposed sanctions against the Russian Federation, which were extended in subsequent years. Russia has responded with countersanctions, choosing the import substitution policy [1].

In this regard, it is advisable to consider works of a Russian scientist D. I. Mendeleev, who is known not only for the discovery of the periodic table of chemical elements but also for research in the field of economics [2]. As an economist and sociologist, in 1903-1906 Mendeleev wrote a book «Treasured Thoughts» dedicated to the most important socioeconomic and political aspects of Russian life: the development of plants and factories, agriculture, education, training of professors, etc. [2]. He claimed that, to develop the domestic industry, it is necessary to create special socio-economic conditions and establish customs for each product, as "protectionism cannot yield full and fruitful results without a

\footnotetext{
*Corresponding author: nvkrivenko@yandex.ru
} 
number of internal measures." Thus, D. I Mendeleev considered the following main conditions (activities) [3]:

- "challenge of internal competition using facilitations for the development of domestic industry;

- patronage of economic activities of residents;

- patronage of education, especially real education."

Nowadays, the Russian economy is considered a catching-up economy: imports are dominated by machinery, equipment and software; exports focus on raw materials. However, falling oil prices and complicated international relations resulted in problems with technological imports and foreign investments, hindering further progress (the model of catch-up development) [4].

Thus, it is advisable for Russia to choose an innovative development strategy, as the Russian economy, being one of the largest in the world, has a developed technical education system. The transition to an innovative economy is essential for promoting economic growth [4].

For the transition to the path of innovative development, Russian science has sufficient potential, obtained knowledge and promising achievements. In particular, Russian scientists were first to discover cloning techniques, stem cells, semiconductor heterostructures for optoelectronics, produce and use nanopowders, examine theoretical possibilities of nanotechnology, etc.

However, successful implementation of innovations requires institutions to support innovation, investment and business activity in relevant fields, developed demand and distribution channels, and a scientific and technological environment including complementary industries, integral for expanded reproduction of a new technological mode [5].

Nowadays, due to the lack of a unified system for measuring and assessing the state, level and real effectiveness of innovative transformations as well as general adaptive models for implementing innovations, it is necessary to examine Russian and international experience [6].

It is essential to consider works of various researchers, who studied the theory of economic development and defined such characteristics as nonequilibrium, unevenness, cyclicality. N. D. Kondratiev discovered long waves and analyzed the impact of changes on the economic development of society [7]. J. Schumpeter was the first to consider the "implementation of new combinations" called innovations that led to changes in technology and management [8]. Richard R. Nelson and Sidney G. Winter, the authors of an evolutionary theory of economic change, stated that long-term economic change means economic progress [9].

S. Kuznets linked innovation with economic growth and new developments in other social spheres, namely, the field of law, institutional structures and even ideology [10]. Simultaneously, technological progress is a complicated (sometimes even painful) social process. The success or failure of new technologies largely depends on the support of interested communities. A change in technological mode is always a process of fierce institutional competition [11].

B. Twiss examined the factors determining the success of innovations (market orientation, compliance with corporate goals, assessment methods, effective project management, creativity, innovative environment, etc.), innovations at different stages of the industry life cycle and methods for assessing the effectiveness of innovative projects [12].

C. Freeman identified the relationship between innovations and social problems concluding that the formation of Kondratiev long cycles affecting all economic areas depends not only on innovation but also on the employment of the population [13]. 
An American economist C. Christensen established a fundamental difference between the types of innovations. Sustaining innovations improve the existing product, but do not ensure the conquest of new markets. Disruptive innovations deliver new products (but not technologies per se) to the market; their application has a disruptive effect [14].

Based on the theory of Kondratiev cycles, a Japanese scientist M. Hirooka calculated that an innovative breakthrough is possible only at the ascendant phase of the Kondratiev long cycle. Using the example of Korea, the researcher showed that a 10 year delay at the beginning of the fourth long cycle led to an innovative breakthrough only 40 years later, at the beginning of the fifth long cycle [15].

An Italian scientist D. Schiliro highlighted the need to strengthen the entrepreneurial culture and promoted the development of small- and medium-sized innovative businesses [16]. K. Verbano, M. Crema and K. Venturini [17] as well as S. Brunswicker and W. Vanhaverbeke [18] considered the development of innovative strategies of enterprises in the context of the open innovation paradigm.

A Russian scientist Yu. V. Yakovets sees innovation as an indispensable part of scientific and technological and economic cycles, necessary for overcoming the crisis. He explored the relationship between scientific, technological, innovation, economic, educational, organizational, and management cycles and their innovation phases. In his opinion, inventive cycles are an integral part of scientific and technological cycles [19].

Considering a difficult geopolitical situation, aggravated by the global crisis due to the COVID-2019 pandemic, it is especially important to study the ongoing import substitution processes in Russia, considering the innovative component.

Table 1 demonstrates changes in certain economic indicators of Russia for the period 2017-2019.

As follows from Table 1, investment in fixed assets in mining exceeds investment in manufacturing and agriculture. Industrial production indices and indicators of agricultural production are showing an upward trend. Simultaneously, negative dynamics of industrial production, growth in mining and a decrease in manufacturing production can be observed.

Expectedly, a decrease in research and development expenditures leads to a decrease in production share of high-tech and knowledge-intensive industries in gross domestic product. While there is an increase in the number of research organizations, the number of design, design and survey organizations, pilot plants, and researchers has decreased. Despite the existing problems, the productivity of scientists, designers, inventors contributed to the growth of advanced production technologies by novelty, indicating the high potential of workers in the Russian science and technology industry.

Exports exceeded imports: in 2019, exports increased compared to 2017, but slightly decreased compared to 2018. The share of Russia in world exports is growing, but remains insignificant.

Due to the sharp depreciation of the national currency, the value of imports increased; however, the complete replacement of imported goods with Russian ones is not possible yet. The items that were previously imported from Western Europe were replaced by goods produced in the countries that did not join Western sanctions, primarily in China and South American countries [20].

At present, mainly energy, military and agricultural products help solve the issues of import substitution and Russian exports [21].

It is advisable to consider the process of import substitution using the example of the agricultural industry and one of the industrial sectors. 
Table 1. Growth (decline) rates of certain economic indicators in Russia for the period 2017-2019

\begin{tabular}{|c|c|c|c|}
\hline Indicators & 2017 & 2018 & 2019 \\
\hline \multicolumn{4}{|c|}{ Investment in fixed assets by type of economic activity, billion rubles } \\
\hline Mining & 3023.2 & 3225.8 & 3282.0 \\
\hline Manufacturing production & 2296.5 & 2513.2 & 2798.3 \\
\hline Agriculture & 705.5 & 781.5 & 838.8 \\
\hline \multicolumn{4}{|c|}{ Indicators (percentage of the previous years) } \\
\hline Industrial production & 103.7 & 103.5 & 103.3 \\
\hline Industrial production indices & 118.2 & 122.3 & 126.4 \\
\hline Labor productivity & 102.1 & 102.8 & 102.0 \\
\hline Agricultural production & 102.9 & 99.8 & 104.3 \\
\hline \multicolumn{4}{|c|}{ Production indices by type of economic activity } \\
\hline Mining & 101.9 & 103.8 & 103.4 \\
\hline Manufacturing production & 105.7 & 103.6 & 103.5 \\
\hline Agriculture & 102.9 & 99.8 & 104.3 \\
\hline \multicolumn{4}{|c|}{ Science and innovations } \\
\hline $\begin{array}{l}\text { Research and development }(\mathrm{R} \& \mathrm{D}) \\
\text { expenditures, percentage of gross domestic } \\
\text { product (GDP) }\end{array}$ & 1.11 & 1.0 & 1.03 \\
\hline Research organizations & 1577 & 1574 & 1618 \\
\hline Design organization & 273 & 254 & 255 \\
\hline Design and survey organizations & 23 & 20 & 11 \\
\hline Pilot plants & 63 & 49 & 44 \\
\hline $\begin{array}{l}\text { The number of researchers (full-time- } \\
\text { equivalent employment) per million } \\
\text { inhabitants }\end{array}$ & 2795.6 & 2764.5 & 2730.3 \\
\hline $\begin{array}{l}\text { Production share of high-tech and knowledge- } \\
\text { intensive industries in gross domestic product }\end{array}$ & 21.8 & 21.1 & $\begin{array}{l}\text { No data } \\
\text { available }\end{array}$ \\
\hline \multicolumn{4}{|c|}{ Advanced production technologies by novelty } \\
\hline Total, including: & 1402 & 1565 & 1620 \\
\hline new for Russia & 1212 & 1384 & 1403 \\
\hline fundamentally new & 190 & 181 & 217 \\
\hline \multicolumn{4}{|c|}{ Indices of exports and imports (billion US dollars) } \\
\hline Exports & 357.3 & 450.3 & 424.4 \\
\hline Imports & 227.9 & 238.7 & 244.3 \\
\hline \multicolumn{4}{|c|}{ The share of Russia in world exports and imports of goods } \\
\hline Exports & 2.1 & 2.4 & 2.3 \\
\hline Imports & 1.3 & 1.2 & 1.3 \\
\hline
\end{tabular}

Source: Russian Statistical Yearbook 2020 https:/rosstat.gov.ru/storage/mediabank/KrPEshqr/year_2020.pdf

In Russia, the formation of competitive advantages in the agricultural industry has its own peculiarities. In the context of counter-sanctions, the import substitution policy has a contradictory effect on the domestic market for food and agricultural raw materials. On the one hand, domestic producers filled a market niche previously occupied by EU suppliers. On the other hand, the dissemination of products from the countries of Southeast Asia and Latin America is increasing. As a result, the key task is to determine the competitive advantages of domestic participants in the Russian food market to improve the food security of the country. The mechanism for the formation of competitive advantages of national agricultural systems requires government support for comprehensive and structural transformations, resulting in an increase in the socio-economic and technological efficiency of the industry and the creation of agro-innovation systems [22]. 
On the one hand, certain success has been achieved in the sphere of import substitution of the agricultural industry, including the introduction of production automation, precision farming, and biotechnology [23].

On the other hand, it is necessary to note the existing negative trends: high depreciation of domestic agricultural equipment, the need to purchase imported equipment, insufficient domestic planting material and seeds, a high proportion of imported breeding herd, etc. [1].

The cancellation of state registration of products and genetically modified organisms to the Russian Federation, in accordance with the Decree of the Government of the Russian Federation dated April 19, 2020 No. 520, may lead to uncontrolled import of GMO products and further affect the quality of domestic agricultural products.

In 2020, despite the COVID-2019 pandemic, the agricultural industry achieved good results: farmers reaped a good harvest, for the first time food exports ( $\$ 29.45$ billion) exceeded imports ( $\$ 28.33$ billion), production volumes and the export of agricultural machinery increased by $30 \%$. [24]

The aviation industry has been chosen as an example among other industrial sectors. This specific industry is characterized by the use of expensive specialized equipment, technologies and materials in the production; creation of high-tech products; a developed industrial infrastructure; highly qualified personnel, etc. The aviation industry plays an important role in strengthening the national defense. Simultaneously, the development of commercial aviation has a positive multiplier effect in the Russian economy.

The aviation industry development program includes the following strategic guidelines: the development of aircraft, helicopter and engine construction in the country, the use of Russian composite materials and advanced technologies, ensuring a high level of project safety, etc.

Nowadays, authorities pay significant attention to the modernization and technical reequipment of the aviation industry, as well as large-scale development and implementation of investment cooperation projects. In 2018, the largest amount of investment in the aviation industry was R\&D expenditures $(68 \%)$. The performance indicators of the aviation enterprises are quite close to the values set in the State Program of the Russian Federation "Aviation Industry Development, 2013-2025." Additionally, there are positive trends in such sectors of the aviation industry as mechanism construction and helicopter construction; however, the share of Russian-made aircraft in domestic and international markets is relatively small [25].

Due to the 1990s reforms, over a thirty-year period, Russia lost its position as one of the largest industrial countries in the world. The production of machine tools fell 20 -fold (in the 1980 s, the country exported them abroad, Japanese researchers adopted the practice of organizing enterprises with computer numerical control machine tools); the production of various types of agricultural machinery decreased by 3-6 times.

The development problems of the Russian aviation industry are largely due to the lack of engineering education among the leaders of the industry. At one time, the Tu-114, which flew N. Khrushchev to the United States, caused a furor; after that, the Americans began to modernize the Boeing. The Il-86 and Il-96 did not have a single crash. The 1990s manifested the destruction of the heritage of the great designers Tupolev, Ilyushin, Yakovlev, Antonov, the destruction of the domestic aviation industry, including regional aviation (the number of airfields decreased by 7 times). Currently, $95 \%$ of passenger traffic is carried out on Boeing, Airbus, Bombardier aircraft. The new Russian aircraft Superjet includes $70 \%$ of imported components and has many technical flaws. After certification, none of the European countries (including the production partners) agreed to purchase it. As the total area of Russia is 17 million square kilometers, the country must be a great aviation power; thus, the revival of the domestic aviation industry is essential [26]. 
The conducted research revealed contradictory trends in the development of Russian import substitution, which are presented in the SWOT matrix (Table 2).

Table 2. SWOT analysis of the state of Russian import substitution, taking into account the innovative component

\begin{tabular}{|c|c|}
\hline Strengths & Opportunities \\
\hline $\begin{array}{l}\text { - Developed fundamental science. } \\
\text { - Successful import substitution that considers } \\
\text { the innovative component of strategically important } \\
\text { industries. } \\
\text { - Defense industry (Russia is a leader in the } \\
\text { production of fast neutron reactors, air defense } \\
\text { systems, etc.). } \\
\text { - Agricultural industry. } \\
\text { - Pharmaceutical industry. } \\
\text { - A world leader in the creation of a highly } \\
\text { effective COVID-2019 vaccine. }\end{array}$ & $\begin{array}{l}\bullet \text { Russia has a rich resource base (one of } \\
\text { the biggest in the world). } \\
\bullet \text { High scientific potential, numerous } \\
\text { scientific schools, developed technical } \\
\text { education system. } \\
\bullet \text { In } 2019-2020 \text {, the Human Development } \\
\text { Index of Russia was } 0.824 \text {, meaning that the } \\
\text { country belongs to the group with very high } \\
\text { human development [27]. }\end{array}$ \\
\hline Weaknesses & Threats \\
\hline $\begin{array}{l}\text { - Insufficient involvement of private sector in } \\
\text { funding and implementation of innovations in the } \\
\text { science and technology industry. } \\
\text { - Contradictory laws concerning the } \\
\text { development of production, state and private } \\
\text { support for domestic producers [28]. } \\
\text { - Insufficient integration of science, research } \\
\text { sector, interdisciplinary studies and production } \\
\text { sectors for the development and implementation of } \\
\text { domestic innovative products. } \\
\text { - Lack of an institutional environment and an } \\
\text { innovative culture aimed at the implementation of } \\
\text { innovations in production. }\end{array}$ & $\begin{array}{l}\text { - Reduced funding of research and } \\
\text { development. } \\
\text { - "Brain drain" of scientists, highly } \\
\text { qualified specialists. } \\
\text { - Lack of engineers, technologists, } \\
\text { designers. } \\
\text { - Decrease in the Global Innovation } \\
\text { Index: in 2020, Russia moved down one } \\
\text { position and placed } 47^{\text {th }}\left(46^{\text {th }} \text { place in 2019) }\right. \\
\text { [29]. }\end{array}$ \\
\hline
\end{tabular}

The COVID-2019 pandemic hindered the economic development of many countries. Thus, Russia has a unique opportunity to reshape its economy, betting on innovative import substitution.

Effective import substitution requires comprehensive government measures for supporting science and technology industry, investing in innovative projects and developments, modernizing industry, and restoring horizontal (between enterprises) and vertical (between research institutes, universities and industries) cooperation.

It is advisable to develop a system of indicators for assessing the characteristics of various industries (Table 3).

The use of this system of indicators (statistical forms) combined with constant monitoring will help determine the level of innovativeness of each industry, import substitution areas to develop the domestic market, and proposals to export breakthrough products. 
Table 3. Cross-sectoral assessment of import substitute products, considering innovativeness

\begin{tabular}{|c|c|c|c|c|c|c|c|}
\hline \multirow[t]{2}{*}{ Industry } & \multicolumn{6}{|c|}{ Indicators } & \multirow{2}{*}{$\begin{array}{c}\text { Cross- } \\
\text { sectoral } \\
\text { assessment } \\
\text { of import } \\
\text { substitute } \\
\text { products }\end{array}$} \\
\hline & 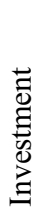 & 莺 & 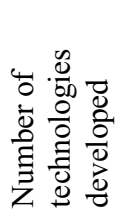 & 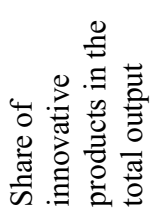 & 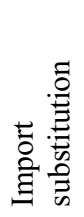 & 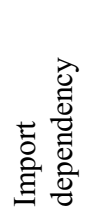 & \\
\hline \multicolumn{8}{|l|}{1} \\
\hline \multicolumn{8}{|l|}{2} \\
\hline ......... & & & & & & & \\
\hline
\end{tabular}

With the support of the government and business, Russia can create an effective mechanism of import substitution, based on the integration of fundamental, applied science, and production. Such a system should consider the innovative component and ensure selfsufficiency and economic and national security of the country

The reported study has been funded by RFBR according to the research project No. 20-010-00153 A «The Influence of the Innovation Import Substitution on Economic Security of the Region.

\section{References}

1. V.A. Chereshnev, V.P. Chichkanov, A.A. Kuklin, Diagnostics and response to threats to socio-economic development of regions (Ekaterinburg: IE UB RAS, 2019)

2. T.N. Belova, Voprosy Ekonomiki, 9, 120-139 (2020)

3. D.I. Mendeleev, Treasured Thoughts (Moscow: Mysl, 1995)

4. S. Vinokurov, P. Gurianov, Soc. and Econ., 12, 37-55 (2020)

5. S.Yu. Glaziev, V.V. Kharitonov, Nanotechnology as a key factor of the new technological order in the economy: a monograph (Moscow: Trovant, 2009)

6. V.N. Kruglov, S.A. Paukov. Reg. Econ.: Theory and Practice, 5, 4-22 (2016)

7. N.D. Kondratiev, Large Cycles of Conjuncture and the Theory of Foreseeing (Moscow: Economy, 2002)

8. J.A. Schumpeter, The Theory of Economic Development (Harvard University Press Cambridge, 1949)

9. S.G. Winter, R.R. Nelson, An Evolutionary Theory of Economic Change (Harvard University Press, 1982)

10. S. Kuznets, Economic Growth: Findings and Reflections (2003)

11. D.P. Frolov, Econ. Anal.: Theory and Practice, 11(304), 12-19 (2013)

12. B. Twiss, Managing Technological Innovation (Longman, 1986)

13. C. Freeman, Long Wave in the World Economy. International Library of Critical Writings in Economics (Aldershot, Edwards Elgar, 1996)

14. C.M. Christensen, M.E. Raynor, The Innovator's Solution: Creating and Sustaining Successful Growth (Boston: Harvard Business School Press, 2003)

15. M. Hirooka, Innovation Dynamism and Economic Growth. A Nonlinear Perspective (Cheltenham, UK: Northampton, 2006)

16. D. Schiliro, Int. J. of Soc. Sci. Stud., 3(5), 148-160 (2015) 
17. C. Verbano, M. Crema, K. Venturini, J. of Small Bus. Man., 53, 1052-1075 (2015)

18. S. Brunswicker, W. Vanhaverbeke, J. of Small Bus. Man., 53, 1241-1263 (2015)

19. Yu.V. Yakovets, Epochal innovations of the XXIst century (Moscow: Economy, 2004)

20. N.V. Krivenko, A.V. Trynov, D.S. Epaneshnikova, Fin. and Cred., 12, 2678-2701 (2020)

21. V.A. Mau, Vopr. Ekon., 3, 5-28 (2019)

22. Yu.G. Lavrikova, Priorities of scientific and technological development of regions: implementation mechanisms (Ekaterinburg: IE UB RAS, 2020)

23. S.A. Svetlakova, N.A. Svetlakova, Perm Agrar. J., 1(17), 1-8 (2017)

24. K. Gurdin, Arg. Ned., 4(748), 7 (2021)

25. P. Kokhno, A. Bondarenko, Soc. And Econ., 12, 74-99 (2020)

26. O. Smirnov, Arg. Ned., 1(745), 6-7 (2021)

27. List of countries by Human Development Index (2020) https://ru.qaz.wiki/wiki/List_of_countries_by_Human_Development_Index

28. L. Ratkin, Invest. In Russia, 12, 42-45 (2020)

29. Global Innovation Index (2020) https://issek.hse.ru/news/396120793.html 